v. 13, n. 1

Vitória-ES, Jan.-Feb. 2016

p. 1 - $23 \quad$ ISSN 1808-2386 DOI: http://dx.doi.org/10.15728/bbr.2016.13.1.1

\title{
Antecedents to Customer Retention in a Corporate Context
}

\author{
Luciene Eberle ${ }^{\dagger}$ \\ Caxias do Sul University
}

Gabriel Sperandio Milan
Caxias do Sul University

Celso Augusto de Matos ${ }^{*}$

Vale dos Sinos University

\begin{abstract}
Strategies for relational practice can vary considerably, depending on which constructs are driving customer retention. In this sense, we developed and tested a theoretical model considering the constructs: perceived value, service provider reputation, trust, and switching costs as antecedents to customer retention. This quantitative descriptive study began from a survey, which was applied to a sample of 269 companies-customers of a health plans operator. The data was analyzed with the use of a structural equation modeling. The results show that the perceived value influences on reputation; that reputation impacts on trust and switching costs; that switching costs are configured as antecedent to customer retention; and that customer retention is influenced by reputation. Finally, the moderating effect of customer time was investigated by means of the hierarchical regression, there being no statistically significant relationship between switching costs and customer retention.
\end{abstract}

Keywords: Perceived value. Reputation. Trust. Switching costs. Customer retention.

* Author for Correspondence:

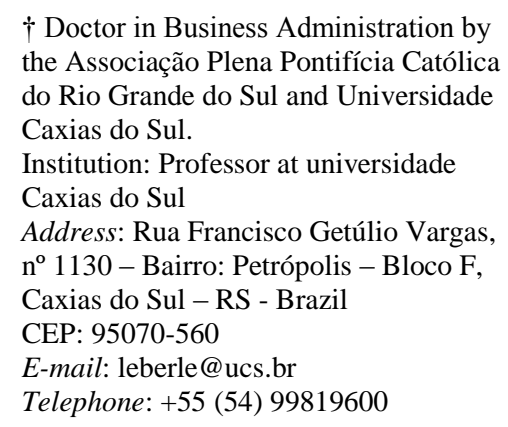

\author{
${ }^{¥}$ Doctor in Administration, with \\ emphasis in Marketing by \\ Universidade Federal do Rio \\ Grande do Sul \\ Institution: Professor at \\ University of Vale dos Sinos \\ Address: Av. Unisinos, no $950-$ \\ Escola de Gestão e Negócios - \\ Sala E07-404C, São Leopoldo - \\ RS - Brazil - CEP: 93022-000 \\ E-mail: celsoam@unisinos.br \\ Telephone: +55 (51) 3591-1122
}

Note from the Editor: The article was accepted by Emerson Mainardes. 


\section{INTRODUCTION}

ustomer retention has been a significant theme in literature since the mid 90's

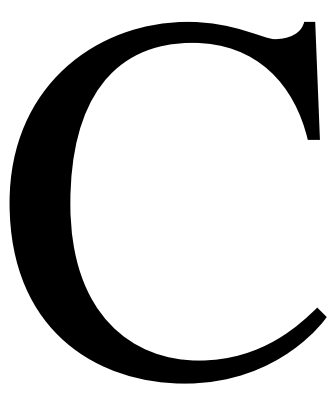
and we verified that the issue remained being studied in the last decade, highlighting its interactionist perspective which is constituted as a longitudinal view of the process of permanence or customer retention (BERGAMO; GIULIANI; GALLI, 2011; KUMAR; POZZA; GANESH, 2013). However, we observe that the studies developed on customer retention in service providers do not present consensus in terms of the definition of their background (VERHOEF, 2003; GUO; JIAN; TANG, 2009).

Service providing companies are being challenged to stand out in a worldwide competitive environment, arousing the interest of academics to exercise efforts to understand how a base of retained, lucrative and profitable clients is formed (MARTIN; PONDER; LUEG, 2009). However, even though there is considerable evidence regarding the impact of lasting relationships on returns and profitability, there still remain gaps in the development of new researches that aim to understand the deepening of the aspects inherent to the antecedents that give shape to customer retention in service providing companies (ANG; WIGHT, 2009).

In parallel with this, Barry, Dion, and Johnson (2008) claim that the existing research gap regarding the antecedents to customer retention is reinforced by the separation of economic and social perspectives, as for example, the perceived value is more relevant in service marketing studies, whilst trust is specially tested in studies on interorganizational behavior or B2B (business-to-business) relations, that is, in corporate contexts. Authors highlight that in this context, strategies aimed at customer retention are discussed from the point of view of perceived value (by the customer), and switching costs as predictors of relationships maintenance (MARQUARDT; GOLICIC; DAVIS, 2011; RAUYRUEN; MILLER; GROTH, 2009). Palmatier et al. (2006) highlight that relationships are strongly linked to results and not only to judgments, and may sometimes be typically shorter and less intense for being focused on profitability and returns.

Based on this discussion, this study's objective is to investigate the factors that influence the relationship continuity of customer-service provider in a B2B service environment, considering that such context is of greater likeness to maintain relationships. The main contribution of the research is to demonstrate the relations between the perceived value, service provider reputation, trust and switching costs constructs as antecedents to customer retention. The paper is structured in the following way: the next section presents the 
theoretical framework and the tested hypothesis, followed by the research method, the tested structural model and the customer time moderation.

\section{THEORETICAL FRAMEWORK AND HYPOTHESIS}

It is important to note, that by carrying out a survey of future research recommendations addressing the constructs to be investigated, gaps are still perceived in the case of the perceived value, reputation, trust and switching costs constructs, as factors that influence customer retention in service providing companies in the context of interorganizational relationships (B2B).

For this reason, the first verified and tested construct is the perceived value, it is expected that this relation to influence direct and positively on the reputation of the service provider (MILAN; DE TONI, 2012; MILAN et al., 2013). Associated with this, in order for the customer to be retained by a service, or to intend to use it again in the future, they must be at least, satisfied with the company and/or with their personnel, having a positive feeling of trust and of perceived value in relation to the service provider (company) and their delivered services (SIRDESHMUKH; SINGH; SABOL, 2002).

On the other hand, the perceived value comprises the standards, rules, criterion, norms or ideas serving as a basis for preferential judgment of customers in relation to service providing companies (BOKSBERGER; MELSEN, 2011). Furthermore, the perceived value is also conceptualized from a utilitarian perspective, which forms an interchange between using versus obtaining a service, that is to say, it is the customer's overall assessment of the usefulness of a perceptions-based service about what is or will be received (LEE; OVERBY, 2004).

Further into understanding the construct, Tai (2011) highlights that the relational dimension of perceived value makes a connection with feelings derived from image, corporate reputation, trust and communication (LINDGREEN; WYNSTRA, 2005), that is, it refers to the positive relational value (results) of a customer in relation to their feelings towards supplier or service provider.

By expanding the discussion, Barry, Dion and Johnson's (2008) study includes the perceived value as a consistent economic antecedent to customer retention in the B2B context, for it reduces a supplier's exchanging uncertainty through reliable and consistent expectations regarding the reputation of the service provider, considering that the intangible nature of service require customers to evaluate subjectively the perceived value of transactions. 
Otherwise, studies by Milan and Toni (2012) and Milan et al., (2013) proved that for service providers, value is an antecedent to trust and that this relationship is mediated by the reputation of the service provider, different from the studies' results by Sirdershmukh, Singh and Sabol (2002) and Perin et al., (2004). Based on this discussion, we propose the following research hypothesis:

$\mathbf{H}_{1:}$ The perceived value positively influences the reputation of the service provider.

The second construct investigated as an antecedent to customer retention was the reputation of the service provider, and we expect it to influence trust direct and positively, switching costs and customer retention. The testing of these relations is based on the fact that reputation has received less attention from researchers regarding the service economy (JÄRVINEN; SUOMI, 2011).

The perceived reputation in service companies has been defined as the customer's belief that the company is fair and honest (DONEY; BARRY; ABRATT, 2007), suggesting that reputation is a symbol of equity, reciprocity, empathy and value to the customer, so that an excellent reputation can greatly improve the company's financial performance.

Beyond that, Michaellis et al. (2008) analyze the relationship of corporate reputation with trust. To this end, the authors addressed the paradox of mutual trust levels between the parties involved, especially when dealing with confidence in the early stage of development of relationships, and, at this stage, confidence can be related to the desire to develop a relational exchange (MAYER; DAVIS; SCHOORMAN, 1995).

Regarding the formation of trust, some studies highlight the existence of some limitations that suggest the development of new researches, by identifying the many facets that guide the formation of reputation and of the service providers trust and its effects when customers have no information or past experiences (JIN; PARK; KIM, 2008; JIANG; HENNEBERG; NAUDÉ, 2011), aiming at expanding and easing a greater understanding inherent to service (POWERS; JACK, 2008).

Trust emerges as another constructor to be analyzed, which was tested in a onedimensional way (MORGAN; HUNT, 1994; JIN; PARK; KIM, 2008). It is important to note that trust is based on the anticipated capacity of the company to regularly meet customer expectations (being related to its credibility and reputation) avoiding doing anything that might be detrimental to the establishment maintenance and longevity of the relationship 
between the parties (CHENET; DAGGER; O’SULLIVAN, 2010; DAGGER; DAVID; NG, 2011).

In the case of trust in a relationship, it is understood as a key antecedent to repurchasing behavior, which is, also being associated with customer retention (RANAWEERA; PRABHU, 2003). Ha, Janda and Muthaly (2010) presented as results in their studies, that trust in the post-satisfaction of a customer can play a significant role, decreasing the distance between customer's appraisal and the behavioral intention to repurchase, rendering a link between reputation and customer retention. Given the above, the following research hypothesis was formulated:

H2: Service provider reputation positively influences customer's trust in the services provider.

We can also observe that when dealing with the reputation of a service provider, suggestions for future researches are focused on testing the relationship of other constructs such as trust and switching costs and their impact on the reputation, with the intention of expanding the existing models in the literature (HELGESEN; NESSET, 2007).

Reputation is defined as a collective assessment of the abilities of a company to provide expected results to a representative group of customers (FOMBRUN, 1996). In the case of a services provider, a high reputation increases switching costs and consequently tends to avoid customer defection (WALSH; DINNIE; WIEDMAN, 2006). However, authors as Jin, Park and Kim (2008) and Jiang, Henneberg and Naudé (2011) reinforce the need to develop new studies that test the direct and positive relation of reputation in switching costs. Thus, the third research hypothesis is presented:

H3: Services provider reputation positively influences switching costs.

Several studies have investigated the importance of switching costs in the continuity of long term relationships, signaling the need to test its influence on customer retention (EDWARD; SAHADEV, 2011; BRUSH; DANGOL; O'BRIEN, 2012; MATOS; HENRIQUE; ROSA, 2013). Switching costs are usually related to the termination of relationships with a current supplier and the establishment of relationships with a new supplier, considering the sacrifices and the penalties that may occur in this change (RANAWERA; PRABHU, 2003; LIU, 2006). Switching costs also refers to perceptions of time, money and efforts related to the alternative supplier available (PATTERSON, 2004). 
Switching costs however, are essential in avoiding that customers change their suppliers (WHITE; YANAMANDRAM, 2007; YEN; WANG; HORNG, 2011). For this reason, many studies began to recognize switching costs as a mean to maintain customer relationships, creating a sort of barrier for the customer's leaving (BANSAL; IRVING; TAYLOR, 2004), for example, by creating mechanisms that generate dependency and locking customers in relationships (ROWE; BARNES, 1998).

In this study, the switching cost construct was tested in a one-dimensional approach, covering the dimensions of procedures, financial and relational costs (BURNHAM; FRELS; MAHAJAN, 2003) because in the case of health services, studies on customer retention highlight that service providing companies should create barriers to customer churn rates (defection), especially through the development of strong interpersonal relationships.

According to Jones, Mothersbaugh and Beatty (2000) and Arnold, Fang and Palmatier (2011), future researches must concentrate their efforts in testing quantitatively the determinants regarding switching costs and its impact on the levels of customer retention. Thus, it is possible to present the following research hypothesis:

H4: Switching costs positively influence customer retention.

Another issue that emerges aims to understand the role of the impact on the reputation of the service provider in customer retention, it is a key issue in an attempt to verify purchasing behavior and customer consumption, which serves as a means of information and communication on the quality of products and/or company services over competitors (NGUYEN; LEBLANC, 2001). In addition to that, a good reputation helps to increase sales volumes from the establishment and maintenance of the relationship with the retained customer (FOMBRUN, 1996; WALKER, 2010).

Antecedents to customer retention investigated consider different perspectives when defining them. After an investigation through scientific papers already published, we realized that there is a gap when dealing with the impact of the reputation of the service provider in customer retention (PARKER; NITSE; TAY, 2009), in order to identify structural attributes and processes that involve customer retention, aiming to improve business success.

In addition, Hidalgo et al. (2008) concluded that customer value on a long-term perspective is hampered by changes in the environment, by the entry of new competitors and by legal changes and, by this fact the reputation of a company may impact the continuity of relationships. Thus, authors suggest the expansion of studies on how the reputation of the 
service provider can affect the relational constructs (BARTIKOWSKI; WALSH; BEATTY, 2011; HESS; HESS, 2008) and its impact on customer retention (MILAN; DE TONI, 2012). Therefore, the following research hypothesis arises:

H5: The reputation of the services provider positively influences customer retention.

The influence of switching costs in customer retention has been addressed. Matos, Henrique and Rosa (2013) highlighted that the higher the switching costs, the greater the possibility of customers keeping their current agreements with their current services providers. Thus, it can be inferred that the greater the time as a customer of a service providing company, the greater the intention to remain retained by continuing to do business with the same service provider, even though an eventual service failure may take place (NETO; SOUZA; SOUKI, 2011; DAGGER; DAVID, 2012).

Furthermore, we noticed an increase of customer retention when customers have a longer relationship time and take notice of higher switching costs. In contrast, under low switching costs, customers who are dissatisfied may change to another services provider whenever they want. Therefore, Amidu and Aluko (2007) claim that customer time, concern the importance of the continuity of customers with the same company over time. Thus, in place with the proposition by Amidu and Aluko (2007) and Matos, Henrique and Rosa (2013), we expected that the difference between the high and low time client, along with the services provider, associated with switching costs can increase customer retention. For this purpose, we propose the following research hypothesis:

H6: Customer time positively moderates the relationship between switching costs and customer retention.

In order to facilitate comprehension, the theoretical model tested with its respective research hypotheses, is shown in Figure 1 


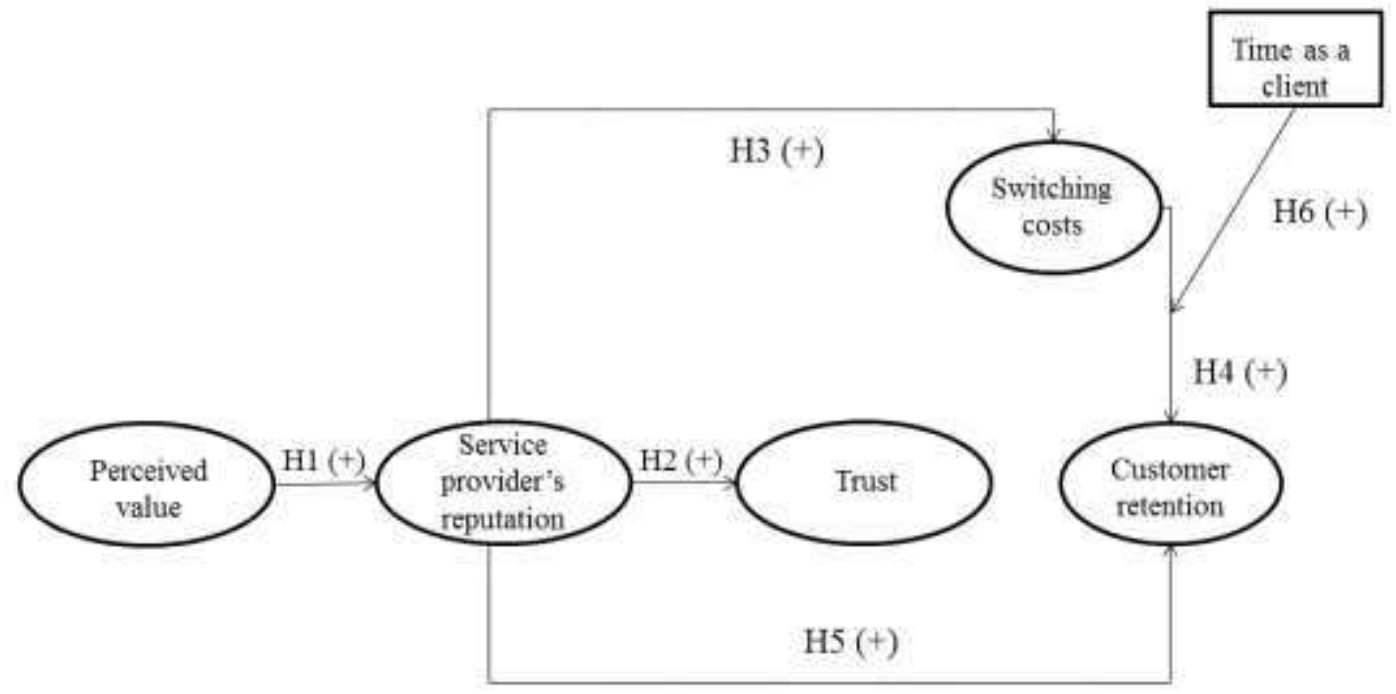

Figure 1 - Proposed Theoretical Model Source: Developed By Authors.

\section{RESEARCH METHOD}

A descriptive quantitative research took place by applying a cross-sectional survey (FINK, 2012). Respondents were senior executives and managers from the human resources and the administrative and financial departments, who are responsible for the negotiation of health insurance contracts at their companies.

The health services operator that served as the ambience of this search has the largest cooperative experience in healthcare and is has the largest health care network in Brazil, covering $83 \%$ of the national territory. We highlight that the particular population for the survey includes customers from business group health plans, situated in the Serra Gaúcha region (gaucho highlands), we chose to work with such a region once the operator has 3128 clients in the business plans.

Next, considering the criteria, we determined a random sample, by the drawing of lots, among the components of the target population (MALHOTRA; BIRKS; WILLS, 2012). In view of the above, the research was applied to a sample of 283 valid cases.

The constructs of the model were measured by the means of a Likert type scale of 7 points (from 1. totally disagree to 7 totally agree), considering that this scale meets the basic requirement of continuous distribution required by the structural equation, which the seven point scale is frequently used by marketing researchers (LARENTIS; GIACOMELLO, 2012), because it is more versatile and has better results in relation to the coefficient of determination $\left(\mathrm{R}^{2}\right)$ (WEIJTERS; CABOOTER; SCHILLEWAERT, 2010). However, for the Perceived Value construct and its respective items we used a semantic differential scale of ten points. It 
is worth mentioning that the scales used were operationalized from previous studies, according to Table 1.

\begin{tabular}{|c|c|c|}
\hline Constructs & Variables & Authors \\
\hline Perceived Value & VALUE_1 to 4 & $\begin{array}{l}\text { Sirdeshmukh, Singh and Sabol (2002), Perin et al. } \\
\text { (2004), Milan and De Toni (2012) and Milan et al. } \\
\text { (2013) }\end{array}$ \\
\hline \multirow{2}{*}{$\begin{array}{l}\text { Services Provider } \\
\quad \text { Reputation }\end{array}$} & REPUT_$_{5} 1$ to 3 to & Ganesan (1994) and Doney and Cannon (1997) \\
\hline & REPUT_4 & Milan and De Toni (2012) and Milan et al. (2013) \\
\hline \multirow{3}{*}{ Trust } & TRU_1 to 7 and 9 & Doney and Cannon (1997) \\
\hline & TRU_8 & $\begin{array}{l}\text { Hewett, Money and Sharma (2002) and Morgan and } \\
\text { Hunt (1994) }\end{array}$ \\
\hline & TRU_1 to 9 & Milan and De Toni (2012) and Milan et al. (2013) \\
\hline \multirow{2}{*}{ Switching Costs } & SWIC_1 to 3 & $\begin{array}{l}\text { Jones, Mothersbaugh and Beatty (2000) and Edward } \\
\text { and Sahadev (2011) }\end{array}$ \\
\hline & SWIC_4 & $\begin{array}{l}\text { Bansal, Irving and Taylor (2004) and Dagger and } \\
\text { David (2012) }\end{array}$ \\
\hline Clint Retention & RETEN_1 to 5 & $\begin{array}{l}\text { Ganesh, Arnold and Reynolds (2000), Milan and De } \\
\text { Toni (2012) e Milan et al. (2013) }\end{array}$ \\
\hline
\end{tabular}

Table 1 - Construct Operationalization

Source: Developed by authors.

Obs.: Scales with Reverse Scores: Reput_3, Tru_2 and 9 and Reten_2 and 5.

Once the survey questionnaire as prepared, we performed the content validation or the face validity (KINNEAR; TAYLOR, 1996). Furthermore, the data collection instrument was submitted to three experts from the field and following up, for its validation a pre-test was applied to eight customers from collective health plans. It is worth mentioning that such cases were not included in the final sample.

\section{DATA PREPARATION}

We decided to include in the sample only questionnaires with complete data (likewise deletion). Thus, out of the 286 questionnaires collected, three were eliminated resulting in 283 valid questionnaires. The next step in the preliminary data analysis was the detection of outliers by using a combination of univariate and multivariate analysis (TABACHNICK; FIDELL, 2012). Firstly, each variable was transformed into a standard score (z scores), and from the univariate atypical observations, we opted for the exclusion of 13 questionnaires. In the next step, the identification of multivariate outliers by calculating the Mahalanobis distance was carried out $\left(D^{2}, p<0,005\right.$ e $\left.d f=30\right)$, for each of the 283 cases of the database. The values found vary from 0.25 to 3.22 . Thus, one case was eliminated from the date base, for it obtained an index value above $|3|$ in calculating the ratio $D^{2} / d f$.

To test the assumptions of multivariate analysis, by analyzing the data, we found that the assumption of normality was achieved, whereas the descriptive statistics varied from 0.263 and 1.379, demonstrating data asymmetry (skewness). Regarding the kurtosis the 
values vary from -0.515 to 3.555 . Regarding the homoscedasticity, linearity and multicollinearity, none of the cases had to be eliminated because all variables followed the recommended values (HAIR JUNIOR et al., 2009).

\section{MODEL SPECIFICATION}

From the definition of the proposed relations, we determined the respective structural equations which characterize the structural and the measurement model, in which the letter "b" represents the structural coefficients and the errors that are the sum between the specification of error and measurement error (HAIR, JUNIOR et al., 2009; BYRNE, 2010; HOYLE, 2012), are represented by the letter "e", as follows:

$$
\begin{aligned}
& \text { REPUT }=\text { b0 + b1 VALUE + e1 } \\
& \text { TRU }=\text { b2 + b3 REPUT + e } 2 \\
& \text { SWIC }=\text { b4 + b5 REPUT + e3 } \\
& \text { RETEN }=\text { b6 + b7 SWIC + b8 REPUT + e4 }
\end{aligned}
$$

For this purpose, we decided that the certificate model is reflective (WILCOX; HOWELL; BREIVIK, 2008). In the case of the data input matrix, the estimation method chosen for the survey was the Maximum Likelihood (MLE) (KLINE, 2011). The tested structural model is shown in Figure 2. 


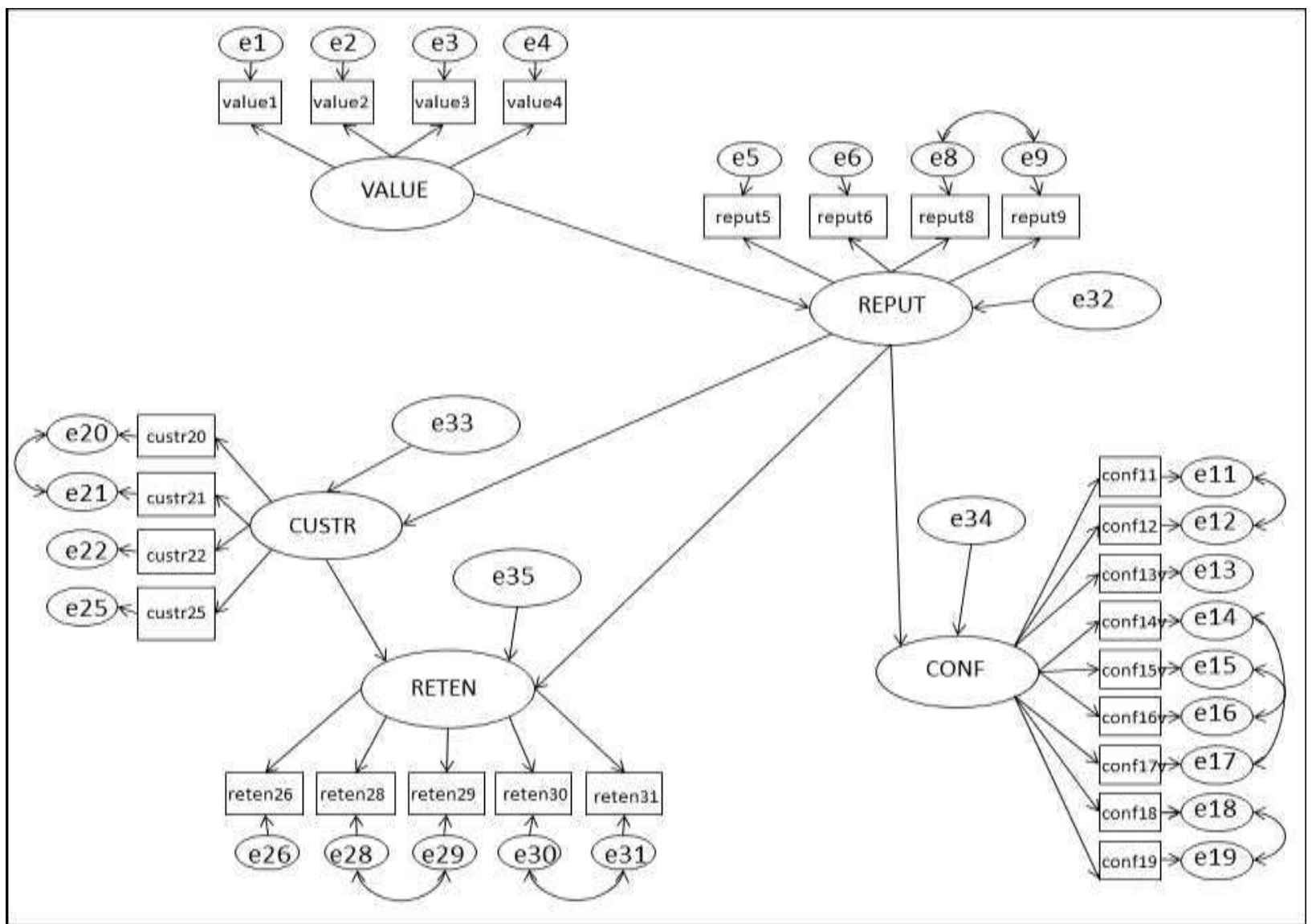

Figure 2 - Structural Model

Source: Developed By Authors

\section{RESULTS}

\subsection{SAMPLE PROFILE}

With the elimination of 14 cases due to outliers, the final sample resulted in 269 valid cases. In the case of the type of company, we noticed that out of the 269 customer-companies of the health plan operator in the sample, $96.2 \%$ are private companies, $1.90 \%$ of public companies are and $1.90 \%$ are joint ventures.

\subsection{MEASUREMENT PROPERTIES}

The individual validation of the constructs aims to validate the integrated model with the respective tested constructs (HAIR JUNIOR et al., 2009; KLINE, 2011). The procedure used for the measurement and analysis of one-dimensionality was the Exploratory Factor Analysis (EFA), with the main components and with the Varimax orthogonal rotation (MULAIK, 2010). Furthermore, we calculated the Cronbach's Alpha considering acceptable indexes greater than or equal to 0.70 (CHURCHILL JUNIOR, 1979).

The verification of the convergent validity of the constructs was preceded by significance analysis of the factor loadings of the variables, based on the t-values of the indicators for each construct, reaching a significance of $(p<0,05)$ (GARVER; MENTZER, 
1999); and by the Confirmatory Factor Analysis (CFA), considering as parameter values above 0.5 (MALHOTRA; BIRKS; WILLS, 2012; KLINE, 2011), as shown in Table 2.

Table 2 - Cronbach's Alphas, Reliability Compounds and the Variance Extracted from the Constructs

\begin{tabular}{c|c|c|c}
\hline Constructs & $\begin{array}{c}\text { Cronbach's } \\
\text { Alphas }\end{array}$ & $\begin{array}{c}\text { Reliability } \\
\text { Compound }\end{array}$ & Extracted Variance \\
\hline Perceived Value & 0,861 & 0,92 & 0,744 \\
\hline Service Provider Reputation & 0,727 & 0,83 & 0,570 \\
\hline Trust & 0,861 & 0,943038 & 0,705 \\
\hline Switching Costs & 0,774 & 0,834267 & 0,560 \\
\hline Client retention & 0,818 & 0,756857 & 0,510 \\
\hline
\end{tabular}

The discriminant validity was assessed by calculating the shared variances, following Fornell and Larcker's method (1981), in which the variances extracted from the constructs are compared with the shared variance, being calculated by correlations between constructs to the square, according to Table 3.

Table 3 - Validity Discriminant

\begin{tabular}{c|c|c|c|c|c}
\hline Constructs & Value & Reputation & Trust & $\begin{array}{c}\text { Switching } \\
\text { Costs }\end{array}$ & $\begin{array}{c}\text { Customer } \\
\text { Retention }\end{array}$ \\
\hline Perceived Value & $\mathbf{0 , 7 4 4}$ & & & \\
\hline $\begin{array}{c}\text { Services Provider } \\
\text { Reputation }\end{array}$ & 0,742 & $\mathbf{0 , 5 7 0}$ & & & \\
\hline Trust & 0,613 & 0,561 & $\mathbf{0 , 7 0 5}$ & & \\
\hline Switching Costs & 0,175 & 0,260 & 0,282 & $\mathbf{0 , 5 6 0}$ & \\
\hline Client Retention & 0,674 & 0,732 & 0,804 & 0,309 & $\mathbf{0 , 5 1 0}$ \\
\hline
\end{tabular}

Obs .: Values in bold: extracted variances. Other values: shared variances.

The results showed that the extracted variance from the Reputation construct $(0.570)$ appeared to be lower than the shared variance with the construct Client Retention (0.732). This result repeats itself in relation to the construct Trust (0.705) with Customer Retention (0.804), and it can demonstrate a possible redundancy between these constructs because they are correlated, though they are different according to theory.

\subsection{TEST OF THE STRUCTURAL MODEL}

The performance of the structural equation model is evaluated according to its adjustment indexes WEST; TAYLOR; WU, 2012). By verifying the adjustment measures tested in the theoretical model, the TLI was 0.911, the CFI 0.922 and the RMSEA was 0.057, and these adjustments measures presented indexes according to what is recommended by literature, which are 0.90 for the CFI and the TLI and values in between 0.05 and 0.08 for the 
RMSEA. As for the GFI, it presented an index of 0.861 and an AGFI of 0.830, presenting values very close to those recommended.

Table 4 - Adjustment Measures of the Theoretical Model

\begin{tabular}{c|c}
\hline Adjustment Measures & Theoretical Model \\
\hline RMR & 0,146 \\
\hline GFI & 0,861 \\
\hline AGFI & 0,830 \\
\hline RMSEA & 0,057 \\
\hline TLI & 0,911 \\
\hline NFI & 0,848 \\
\hline CFI & 0,922 \\
\hline
\end{tabular}

Next, we conducted a hypothesis test, examining the significance and magnitude of the estimated regression coefficients. Table 5 presents the hypothesis, the structural paths, nonstandardized coefficients, standard errors, the standardized coefficients, t-values and the probabilities.

Table 5 - Hypothesis Test

\begin{tabular}{c|c|c|c|c|c|c|c}
\hline Hi & Structural Paths & $\begin{array}{c}\text { Non- } \\
\text { Standardized } \\
\text { Coefficients (b) }\end{array}$ & $\begin{array}{c}\text { Erro } \\
\mathbf{r}\end{array}$ & $\begin{array}{c}\text { Standard Error } \\
(\boldsymbol{\beta})\end{array}$ & t-values & $\mathbf{p}$ & Results \\
\hline H1 & VALUE $\rightarrow$ REPUT & 0,362 & 0,043 & 0,704 & 8,443 & 0,001 & Supported \\
\hline H2 & REPUT $\rightarrow$ TRU & 1,006 & 0,106 & 0,900 & 9,479 & 0,001 & Supported \\
\hline H3 & REPUT $\rightarrow$ SWIC & 0,353 & 0,157 & 0,174 & 2,252 & 0,024 & Supported \\
\hline H4 & SWIC $\rightarrow$ RETEN & 0,127 & 0,041 & 0,181 & 3,121 & 0,002 & Supported \\
\hline H5 & REPUT $\rightarrow$ RETEN & 1,346 & 0,181 & 0,940 & 7,421 & 0,001 & Supported \\
\hline
\end{tabular}

Obs.: 0.05 significance level.

According to the results, the first five hypothesis of the research were statistically supported. In addition, another way to verify the effectiveness of the hypothesis test is through the coefficients of determination $\left(\mathrm{R}^{2}\right.$ ) (HAIR JUNIOR et al., 2009). The $\mathrm{R}^{2}$ of the theoretical model are presented in Table 6.

Table 6 - Coefficients of Determination

\begin{tabular}{c|c}
\hline Constructs & Coefficients of Determination $\left(\mathbf{R}^{\mathbf{2}}\right)$ \\
\hline Service Provider Reputation & 0,496 \\
\hline Trust & 0,811 \\
\hline Switching Costs & 0,300 \\
\hline Customer Retention & 0,976 \\
\hline
\end{tabular}

When dealing with coefficients of determination $\left(\mathrm{R}^{2}\right)$, we observed the following results for the structural model: $97.6 \%$ of the variance for Customer Retention is explained by its 
independent variables, in this case, Switching Costs, Trust, Service Provider Reputation and Perceived Value.

\subsection{CUSTOMER RELATIONSHIP TIME AS MODERATOR}

When testing the moderating effect in the proposed model (customer time), we estimated the parameters simultaneously for each group (HAYES, 2013; JOSE, 2013): (i) companies that had short customer time; and (ii) companies with long customer time, according to the indexes of the standardized coefficients. For this purpose, out of the 269 valid cases, a subsample with the first group of companies presented an $n=126$ (46.8\%), who had an average customer time of 3.90 years, while the second group of companies resulted in $\mathrm{n}=143(53.20 \%)$ with an average customer time of 10.97 years. The variance analysis proved the statistics difference of the group means. Such a division led to the analysis of two new subsamples, as shown in Table 7.

Table 7 - Mean Difference Between Groups

\begin{tabular}{c|c|c|c|c}
\hline Independent variables & Subsample (n) & Mean & Standard Error & Sig. \\
\hline Short customer relationship time & 126 & 3,90 & 1,44 & \\
\hline Long customer relationship time & 143 & 10,97 & 8,01 & $0,000^{*}$ \\
\hline
\end{tabular}

Obs.: (*) Significant Means

Thus, it was found that the customer time moderating effect was not significant for the paths switching costs and customer retention (SWIC $\rightarrow$ RETEN, $p=0.828$ ) for the groups with customer time short and long, since the effects were not confirmed in the tested model. However, a limitation of the above test is that the sample size in each group was relatively small, that is, lower than 150 , although the number of cases per variable of the model has been close to 5, even in the smallest group (HAIR JUNIOR et al., 2009; GARSON, 2012).

With a relatively small sample in each group, it may be that the test has not achieved sufficient statistical power to detect a significant difference. For this reason, we conducted an additional test, in using the hierarchical regression, which had as dependent variable customer retention. In the first model, we considered the switching costs and customer time as independent variables. In the second model though, we added into the first the interaction term customer time $*$ switching costs. The variables were centered in the mean before computing the interaction term, in order to reduce multicollinearity problems (JACCARD; TURRISI, 2003). The results are shown in Table 8. 
Table 8 - Moderation via Hierarchical Regression

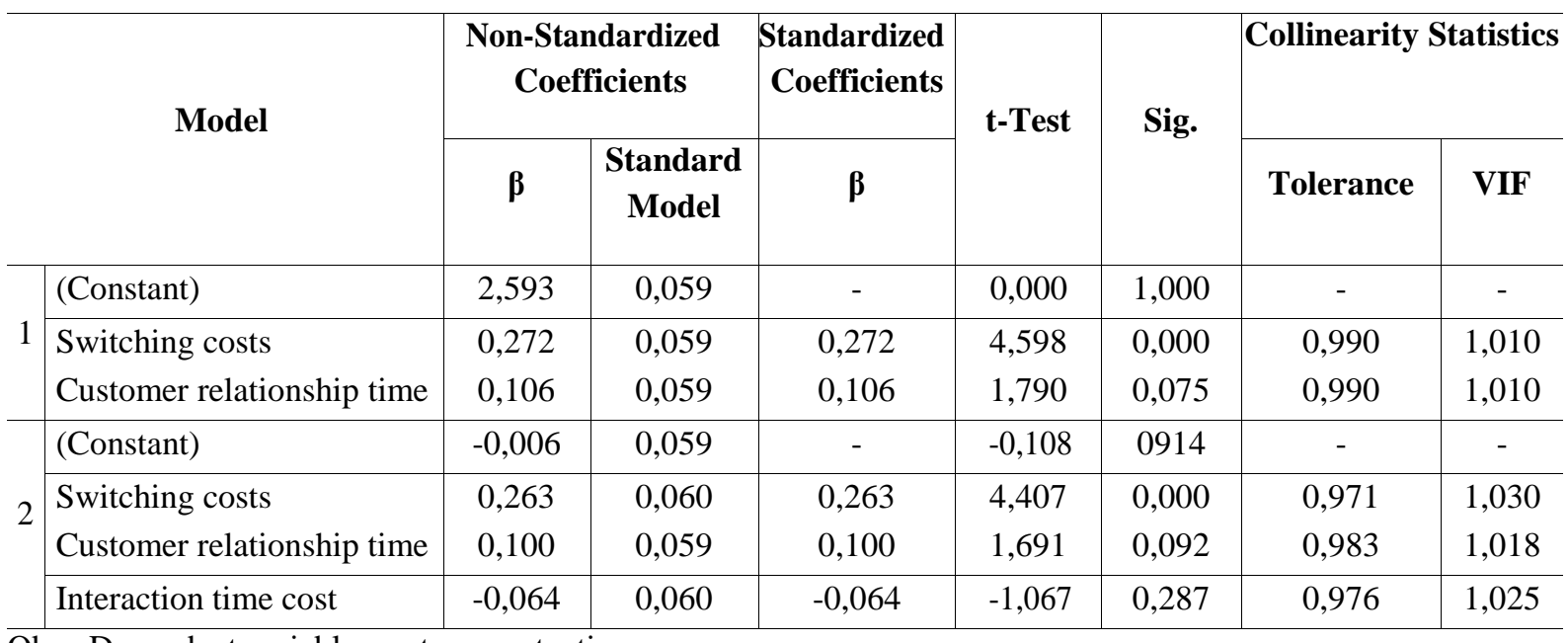

Obs.: Dependent variable: customer retention

By analyzing the hierarchical regression, the results for the $t$ test value, considering customer time interaction with switching costs $=-1.067$, with statistical significance of $\mathrm{p}=$ 0.287, results so that such moderation is not significant at $0.05 \%$ (HAIR JUNIOR et al., 2009).

By testing the effect of customer time moderation in the proposed model, we estimated the model simultaneously, for each group through structural equation modeling and hierarchical multi group regression. However, we observed that the final coefficients do not vary. Consequently, it is possible to state that the relationship between switching costs and customer retention is not moderated by customer time. That is, hypothesis $\mathbf{H 6}$ (customer time positively moderates the relationship between switching costs and customer retention) ( $\beta=-$ $0.064, p=0.287$ ) was not statistically supported, confirming the results previously presented and discussed, evidencing that this relationship needed a greater theoretical and empirical maturity.

\section{FINAL CONSIDERATIONS}

The tested model provided a nomological structure of the constructs forming the continuity of proper relationships in a B2B services environment (BARRY; DION; JOHNSON, 2008), with the intention of understanding the relationship of the antecedents of customer retention. Considering the service sector, the evidence of the hypothesis $\mathbf{H 1}$ and $\mathbf{H 2}$ demonstrate that in corporative markets (B2B), service providing companies must focus their efforts to develop greater competitiveness through a higher reputation, based on the creation of differentials by providing greater aggregated values (MARQUARDT; GOLICIC; DAVIS, 2011). 
Another theoretical contribution was the confirmation of the positive and direct relationship between the reputation of the service provider with the switching costs, and indirectly in customer retention, which was confirmed in the proposed Theoretical Model. Seen in these terms, the study by Walsh, Dinnie and Wiedmann (2006) also demonstrated the positive effect of the service provider's reputation on the switching costs, particularly in service businesses, considering that if the reputation is positively perceived by customers, switching costs become more evident and potentially higher.

The third finding supported by the proposed theoretical model is the confirmation of the positive effect of the relationship between switching costs on customer retention. We verified that in B2B businesses, investments in personnel, physical infra-structure and in intrinsic procedures to customer service may lead customers to hesitate in incurring contractual interruptions, and to begin considering the switching costs involved in choosing new suppliers (BARRY; DION; JOHNSON, 2008).

With respect to the direct relationship of the service provider's reputation on customer retention, we registered that reputation may serve as an element that helps to predict a future purchasing behavior, and therefore, the reputation attests, more prominently, that the company is qualified to meet and even exceed customers' expectations (WALSH; BEATTY; SHIU, 2009).

It is made noticeable that the study still brings as a contribution the non-confirmation of the moderating effect of customer time with the service provider and switching costs and customer retention (H6), demonstrating that the effects of interaction and moderation need a greater theoretical maturity, indicating that depending on the context being studied, it indeed does not come to be a relevant aspect that may, by itself, strengthen existing relationships.

As managerial implications, it is recommended that managers should be effective in developing programs that aim at conducting a detailed assessment of customer expectations of collective health plans and that this assessment should be monitored constantly, with the intent of finding out the motives that may lead to the search of new health plan service providers (MILAN; TREZ, 2005; RAMSARAN-FOWDAR, 2013).

In sum, the theoretical contributions are focused on the development of a theoretical model, which was structured and tested in a Brazilian scenario by combining the different variables from the studies verified in the literature, thus representing an evolution of the concepts empirically tested, as well as awakening the need for the conduction of new studies 
around the theme. As such, the present study contributes so that significant relationships are found between the Perceived Value, Service Provider's Reputation, Trust and the Switching Costs as antecedents to Customer Retention, which may result in increased profitability and earnings, and consequently, increased competition for service providers.

As a development of future studies, we suggest the replication of the theoretical model in B2C (Business-to-Consumer) relationships, and in different contexts of service provision, as it is the case of financial and telephony services. The possibility arises to test other constructs and alternative relationships that stand out in the literature as possible antecedents to customer retention, as for example, commitment, binding tactics and others. As for the model specification, it would also be possible to test the switching costs as a mediator between trust and customer retention.

Finally, we highlight that the theoretical model tested should not be considered as final and therefore, it is relevant to continuously stimulate the development, the testing and the comparison of this model to alternative ones, with the intent to improve the theoretical and empirical developments around the relational practice.

\section{REFERENCES}

AMIDU, A.; ALUKO, B. T. Client influence in residential property valuations: na empirical study. Property Management, v. 25, n. 5, p. 447-461, 2007.

ANG, S. H.; WIGHT, A. Building intangible resources: the stickiness of reputation. Corporate Reputation Review, v. 12, n. 1, p. 21-32, 2009.

ARNOLD, T. J.; FANG, E.; PALMATIER, R. W. The effects of customer acquisition and retention orientations on a firm's radical and incremental innovation performance. Journal of the Academic Marketing Science, v. 39, p. 234-251, 2011.

BANSAL, H. S.; IRVING, P. G.; TAYLOR, S. F. A three-component model of customer commitment to service providers. Journal of the Academy of Marketing Science, v. 32, n. 3, p. 234-250, 2004.

BARRY, J. H.; DION, P.; JOHNSON, W. A cross-cultural examination of relationship strength in B2B services. Journal of Services Marketing, v. 22, n. 2, p. 114-135, 2008.

BARTIKOWSKI, B.; WALSH, G.; BEATTY, S. E. Culture and age as moderators in the corporate reputation and loyalty relationship. Journal of Business Research, v. 64, p. 966-972, 2011.

BERGAMO, F. V. M.; GIULIANI, A. C.; GALLI, L. C. L. A. Modelo de lealdade e retenção de alunos para instituições do ensino superior: um estudo teórico com base no marketing de relacionamento. BBR - Brazilian Business Review, v. 8, n. 2, p. 43-67, 2011. 
BOKSBERGER, P. E.; MELSEN, L. Perceived value: a critical examination of definitions, concepts and measures for the service industry. Journal of Services Marketing, v. 25, n. 3, p. 229-240, 2011.

BRUSH, T. H.; DANGOL, R.; O'BRIEN, J. P. Customer capabilities, switching costs, and bank performance. Strategic Management Journal, v. 13, n. 13, p. 1.499-1.515, 2012.

BURNHAM, T. A.; FRELS, J. K; MAHAJAN, V. Consumer switching costs: a typology antecedents, and consequences. Journal of the Academy of Marketing Science, v. 31, p. 109-126, 2003.

BYRNE, B. M. Structural equation modeling with AMOS: basic concepts applications, and programming. 2. Ed. New York: Routledge, 2010.

CHENET, P.; DAGGER, T. S.; O'SULLIVAN, D. Service quality, trust, commitment and service differentiation in business relationships. Journal of Services Marketing, v. 24, n. 5, p. 336-346, 2010.

CHURCHILL JUNIOR, G. A. Paradigm for developing better measures of marketing constructs. Journal of Marketing Research, v. 16, p. 64-73, 1979.

DAGGER, T. S.; DAVID, M. E. Uncovering the real effect of switching costs on the satisfaction-loyalty association: the critical role of involvement and relationship benefits. European Journal of Marketing, v. 36, n. 3/4, p. 447-468, 2012.

DAGGER, T. S.; DAVID, M. E.; NG, S. Do relationship benefits and maintenance drive commitment and loyalty? Journal of Services Marketing, v. 25, n. 4, p. 273-281, 2011.

DONEY, P.; CANNON, J. P. An examination of the nature of trust in buyer-seller relationships. Journal of Marketing, v. 61, n. 2, p. 35-51, 1997.

DONEY, P. M.; BARRY, J. M.; ABRATT, R. Trust determinants and outcomes in global B2B services. European Journal of Marketing, v. 41, n. 9/10, p. 1.096-1.116, 2007.

EDWARD, M.; SAHADEV, S. Role of switching costs in the service quality, perceived value, customer satisfaction and customer retention linkage. Asia Pacific Journal of Marketing and Logistics, v. 22, n. 3, p. 327-345, 2011.

FINK, A. How to conduct surveys: a step-by-step guide. 5. Ed. Thousand Oaks: Sage Publications, 2012.

FOMBRUN, C. J. Reputation: realizing value from the corporate image. Boston: Harvard Business School Press, 1996.

FORNELL, C.; LARCKER, D. Evaluating structural equation models with unobserved variables and measurement error. Journal of Marketing Research, v. 18, n. 1, p. 39-50, 1981.

GANESAN, S. Determinants of long-term orientation in buyer-seller relationships. Journal of Marketing, v. 58, n. 2, p. 1-19, 1994. 
GANESH, J.; ARNOLD, M. J.; REYNOLDS, K. Understanding the customer base of service providers: an examination of the differences between switchers and stayers. Journal of Marketing, v. 64, n. 3, p. 65-87, 2000.

GARSON, D. Structural Equation Modeling. Blue Book Series. Asherobo, Statical Associates Publishing, 2012.

GARVER, M. S.; MENTZER, J. T. Logistics research methods: employing structural equation modeling to test for construct validity. Journal of Business Logistics, v. 20, n. 1, p. 33-57, 1999.

GUO, L.; JIAN, J. X.; TANG, C. Understanding the psychological process underlying customer satisfaction and retention in a relational service. Journal of Business Research, v. 62 , p. 1.152-1.159, 2009.

HA, H.; JANDA, S.; MUTHALY, S. Ane wunderstanding of satisfaction model in e-repurchase situation. European Journal of Marketing, v. 44, n. 7/8, p. 997-1.016, 2010.

HAIR JUNIOR, J. F. et al. Análise multivariada de dados. 6. ed. Porto Alegre: Bookman, 2009.

HAYES, A. F. Introduction to mediation, moderation, and conditional process analysis a regression-based approach. New York: The Guilford Press, 2013.

HELGESEN, O.; NESSET, E. Images, satisfaction and antecedents: drivers of student loyalty? A case study of a Norwegian University College. Corporate Reputation Review, v. 10, n. 1, p. 38-59, 2007.

HESS JUNIOR, J.; HESS, R. L. The impact of firm reputation and failure severity on customer's responses to service failures. Journal of Services Marketing, v. 22, n. 5, p. 385398, 2008.

HEWETT, K.; MONEY, R. B.; SHARMA, S. An exploration of the moderating role of buyer corporate culture in industrial buyer-seller relationships. Journal of the Academy of Marketing Science, v. 30, n. 3, p. 229-239, 2002.

HIDALGO, P. et al. Customer retention and price matching: the AFPs case. Journal of Business Research, v. 61, p. 691-696, 2008.

HOYLE, R. H. Assumptions in Structural Equation Modeling. In: HOYLE, R. H. (Ed.). Handbook of structural equation modeling. New York: The Guilford Press, 2012. Chapter 8, p. 126-144.

JACCARD, J.; TURRISI, R. Interaction effects in multiple regression. 2. Ed. Thousand Oaks: Sage University Paper, 2003.

JÄRVINEN, R.; SUOMI, K. Reputation attributes in retailing services: managerial perspective. Managing Service Quality, v. 21, n. 4, p. 410-423, 2011. 
JIANG, Z.; HENNEBERG, S. C.; NAUDÉ, P. The importance of trust vis-à-vis reliance in business relationships: some international findings. International Marketing Review, v. 28, n. 4, p. 318-339, 2011.

JIN; B.; PARK; J. Y.; KIM, J. Cross-cultural examination of the relationships among firm reputation e-satisfaction, e-trust and e-loyalty. International Marketing Review, v. 25, n. 3, p. 324-337, 2008.

JONES, M. A.; MOTHERSBAUGH, D. L; BEATTY, S. E. Switching barriers and repurchase intentions in services. Journal of Retailing and Consumer Services, v. 76, n. 2, p. 259-274, 2000.

JOSE, P. E. Doing statistical mediation and moderation. New York: The Guilford Press, 2013.

KINEAR, T. C.; TAYLOR, J. R. Marketing research: an applied approach. 5. Ed. New York: McGraw-Hill, 1996.

KLINE, R. B. Principles and practice of structural equation modeling. 3. Ed. New York: The Gilford Press, 2011.

KUMAR, V.; POZZA, I. D.; GANESH, J. Revisiting the satisfaction-loyalty relationship: empirical generalizations and directions for future research. Journal of Retailing, v. 89, n. 3, p. 246-262, 2013.

LARENTIS, F.; GIACOMELLO, C. P. Análise da importância em pesquisas de satisfação através da regressão múltipla: estudo do efeito de diferentes pontos de escala. In:

ENCONTRO DE MARKETING (EMA), 5., 2012, Curitiba (PR). Anais... Curitiba: ANPAD, 2012.

LEE, E.; OVERBY, J. W. Creating value for online shoppers: implications for satisfaction and loyalty. Journal of Satisfaction, Dissatisfaction and Complaining Behavior, v. 17, 2004.

LI, R. X.; PETRICK, J. F. Towards an integrative model of loyalty formation: the role of quality and value. Leisure Sciences, v. 32, n. 3, p. 201-221, 2010.

LINDGREEN, A.; WYNSTRA, F. Value in business markets: what do we know where are we going? Industrial Marketing Management, v. 34, n. 7, p. 732-748, 2005.

LIU, A. H. Customer value and switching costs in business services: developing exit barriers through strategic value management. Journal of Business \& Industrial Marketing, v. 21, n. 1, p. 30-37, 2006.

MALHOTRA, N. K.; BIRKS, D.; WILLS, P. Marketing research: applied approach. 4. Ed. New York: Pearson, 2012.

MARQUARDT, A. J.; GOLICIC, S. L.; DAVIS, D. F. B2B services branding in the logistics services industry. Journal of Service Marketing, v. 25, n. 1, p. 47-57, 2011. 
MARTIN, W. C.; PONDER, N.; LUEG, J. E. Price fairness perceptions and customer loyalty in a retail context. Journal of Business Research, v. 62, p. 588-593, 2009.

MATOS, C. A.; HENRIQUE, J. L.; ROSA, F. Customer reactions to service failure and recovery in the banking industry: the influence of switching costs. Journal of Services Marketing, v. 27, n. 7, p. 526-538, 2013.

MAYER, R. C.; DAVIS, J. H.; SCHOORMAN, F. D. An integrative model of organizational trust. Academy of Management Review, v. 30, n. 3, p. 709-734, 1995.

MICHAELIS, M. et al. The effects of country of origin and corporate reputation on initial trust. International Marketing Review, v. 25, n. 4, p. 404-422, 2008.

MILAN, G. S. et al. The relational practice existing between a service provider and its customers and the customer retention: a comparison between a theoretical model and rival. Australian Journal of Basic and Applied Sciences, v. 7, n. 7, p. 904-915, 2013.

MILAN, G. S.; DE TONI, D. A construção de um modelo sobre a retenção de clientes e seus antecedentes em um ambiente de serviço. REAd - Revista Eletrônica de Administração, v. 18, n. 2, p. 433-467, 2012.

MILAN, G. S.; PRESTES, A. R.; MUNHOZ, L. P. S. Análise do valor do cliente (lifetime value): um estudo ambientado em uma operadora de planos de saúde. BASE - Revista de Administração e Contabilidade, v. 7, n. 2, p. 123-134, 2010.

MILAN, G. S.; TREZ, G. Pesquisa de satisfação: um modelo para planos de saúde. RAE Revista de Administração de Empresas, v. 4, n. 2, 2005.

MORGAN, R. M.; HUNT, S. D. The commitment-trust theory of relationship marketing. Journal of Marketing, v. 58, n. 3, p. 20-38, 1994.

MULAIK, S. A. Foundations of factor analysis. 2. Ed. Boca Raton: Taylor \& Francis Group, 2010.

NETO, M. T. R.; SOUZA, J.; SOUKI, Q. Identifying variables that predict clients propensity to end their checking accounts. International Journal of Bank Marketing, v. 29, n. 6, p. 489-507, 2011.

NGUYEN, N.; LEBLANC, G. Corporate image and corporate reputation in customers retention decisions in services. Journal of Retailing and Consumer Services, v. 8, p. 227 236, 2001.

PALMATIER, R. W. et al. Factors influencing the effectiveness of relationship marketing: a meta-analysis, Journal of Marketing, v. 70, n. 4, p. 136-153, 2006.

PATTERSON, P. G. A contingency model of behavioural intentions in a services context. European Journal of Marketing, v. 38, n. 9/10, p. 1.304-1.315, 2004. 
PARKER, K. R.; NITSE, P.; TAY, A. S. M. The impact of inaccurate color on customer retention and CRM. Informing Science: the International Journal of an Emerging Transdiscipline, v. 12, p. 105-121, 2009.

PERIN, M. G. et al. As relações entre confiança, valor e lealdade: um estudo intersetorial. In: ENCONTRO ANUAL DA ASSOCIAÇÃO NACIONAL DOS PROGRAMAS DE PÓSGRADUAÇÃO EM ADMINISTRAÇÃ̃O (ENANPAD), 28., 2004, Curitiba (PR). Anais... Curitiba: ANPAD, 2004.

POWERS, T. L.; JACK, E. P. Using volume flexible strategies to improve customer satisfaction and performance in health care service. Journal of Services Marketing, v. 22, n. 3, p. 188-197, 2008.

RAMSARAN-FOWDAR, R. R. Assessing the influence of switching barriers on patients' expectations and tolerance zone. International Journal of Health Care Quality Assurance, v. 26, n. 2, p. 226-249, 2013.

RANAWEERA, C.; PRABHU, J. The influence of satisfaction, trust and switching barriers on customer retention in a continuous purchasing setting. International Journal of Service Industry Management, v. 14, n. 4, p. 374-395, 2003.

RAUYRUEN, P.; MILLER, K. E.; GROTH, M. B2B services: linking service loyalty and brand equity. Journal of Services Marketing, v. 23, n. 3, p. 175-186, 2009.

ROWE, W. G.; BARNES, J. G. Relationship marketing and sustained competitive advantage. Journal of Market Focused Management, v. 2, n. 3, p. 281-297, 1998.

SIRDESHMUKH, D.; SINGH, J.; SABOL, B. Consumer trust, value, and loyalty in relational exchanges. Journal of Marketing, v. 66, n. 1, p. 15-37, 2002.

TABACHNICK, B. G.; FIDELL, L. S. Using multivariate statistics. $6^{\text {th }}$ edition, Boston: Pearson, 2012.

TAI, Y. Perceived value for customers in information sharing services. Industrial Management \& Data Systems, v. 111, n. 4, p. 551-569, 2011.

VERHOEF, P. C. Understanding the effect of customer relationship development. Journal of Marketing, v. 67, n. 4, p. 30-45, 2003.

WALKER, K. A systematic review of the corporate reputation literature: definition, measurement, and theory. Corporate Reputation Review, v. 12, n. 4, p. 357-387, 2010.

WALSH G.; BEATTY, S. E.; SHIU E. The customer-based corporate reputation scale: replication and short form. Journal Business Research, v. 62, n. 10, p. 924-930, 2009.

WALSH, G.; DINNIE, K.; WIEDMANN, K. How do corporate reputation and customer satisfaction impact customer defection? A study of private energy customers in Germany. The Journal of Services Marketing, v. 20, n. 6, p. 412-420, 2006. 
WEIJTERS, B.; CABOOTER, E.; SCHILLEWAERT, N. The effect of rating scale format on response styles: the number of response categories and response category labels.

International Journal of Research Marketing, v. 27, n. 3, p. 236-247, 2010.

WEST, S. G.; TAYLOR, A. B.; WU, W. Model fit and model selection in structural equation modeling. In: HOYLE, R. H. (Ed.). Handbook of structural equation modeling. New York: The Guilford Press, 2012. Chapter 13, p. 209-231.

WHITE, L.; YANAMANDRAM, V. A model of customer retention of dissatisfied business services customers. Managing Service Quality, v. 17, n. 3, p. 298-316, 2007.

WILCOX, J. B.; HOWELL, R. D.; BREIVIK, E. Questions about formative measurement. Journal of Business Research, v. 61, n. 12, p, 1.219-1.228, 2008.

YEN, Y.; WANG, E. S.; HORNG, D. Supplier's willingness of customization, effective communication, and trust: a study of switching cost antecedents. Journal of Business \& Industrial Marketing, v. 26, n. 4, p. 250-259, 2011. 